\title{
Historical changes of bottom topography and tidal amplitude in the Ria de Aveiro, Portugal - trends for future evolution
}

\author{
José Figueiredo da Silva ${ }^{1, *}$, Robert W. Duck ${ }^{2}$ \\ ${ }^{1}$ Departamento de Ambiente e Ordenamento, Universidade de Aveiro, 3800 Aveiro, Portugal \\ ${ }^{2}$ Department of Geography, University of Dundee, Dundee DD1 4HN, Scotland, UK
}

\begin{abstract}
The natural evolution of the estuary-coastal lagoon system of the Ria de Aveiro, Portugal, was halted in 1808 by the construction of a new inlet/outlet channel through the sand spit which isolates it from the Atlantic Ocean. In consequence, tidal amplitudes in the lagoon increased from $0.07-0.13 \mathrm{~m}$ to over $1 \mathrm{~m}$. Improvements to the channel since 1936, including construction of jetties, breakwaters and dredging, have increased its cross-sectional area. This has caused a steady increase in tidal amplitude to between 2.5 and $2.8 \mathrm{~m}$, the erosion of mud flats, salt marsh and old salt pans, the widening and deepening of channels, and a greater capacity for sediment transport and dispersal due to the increased tidal currents. The volume of the tidal prism calculated for spring tides is now 1.7 times that in 1951; thus areas bordering the lagoon, especially agricultural fields, are experiencing a progressively increasing risk of flooding and salt water contamination at high water. Any future increase of mean sea level will contribute to an increase of both area and volume of the water mass and could cause important changes to the dynamics of the system. An increase in mean sea level of $0.1 \mathrm{~m}$ will, for example, correspond to an increase of $5 \%$ in the capacity of the system and contribute to an increase in the speed of tidal propagation. The resulting increase in the volume of the tidal prism will be up to $22 \%$ of the present maximum value.
\end{abstract}

KEY WORDS: Coastal lagoon - Tidal changes $\cdot$ Morphological evolution $\cdot$ Sea level rise $\cdot$ Ria de Aveiro

Resale or republication not permitted without written consent of the publisher

\section{INTRODUCTION}

The Ria de Aveiro is the most remarkable geomorphological feature of the Atlantic Ocean coast of northern Portugal (Fig. 1). Although it is designated as a 'ria', the water body bears no resemblance to the Galician rias of northwest Spain to the north, and a more accurate description is an 'estuary-coastal lagoon' system. The system is characterised by many branching fluvial channels that are connected to the ocean by a single tidal channel, via an intervening tidal lagoon (Fig. 1). It originated and evolved rapidly during the

\footnotetext{
*E-mail: jfs@mail.ua.pt
}

Holocene (Rodrigues \& Dias 1989), after sea level became stable, ca 3000 yr BP. Important characteristics of the lagoon are its shallow water column and the large areas of intertidal mud flats and salt marshes. The lagoon is a zone of accumulation for fine sediments supplied by influent rivers and for marinederived materials.

The lagoon of the Ria de Aveiro is thus the estuary of several small streams, with catchment areas ranging from 30 to $300 \mathrm{~km}^{2}$. However the $2400 \mathrm{~km}^{2}$ catchment of one major influent, the River Vouga (Fig. 1), represents $70 \%$ of the total drainage area. A large part of the catchment area of the River Vouga is underlain by schist (Cambrian age) and granites (Hercynian syntectonic), which are characterised by 


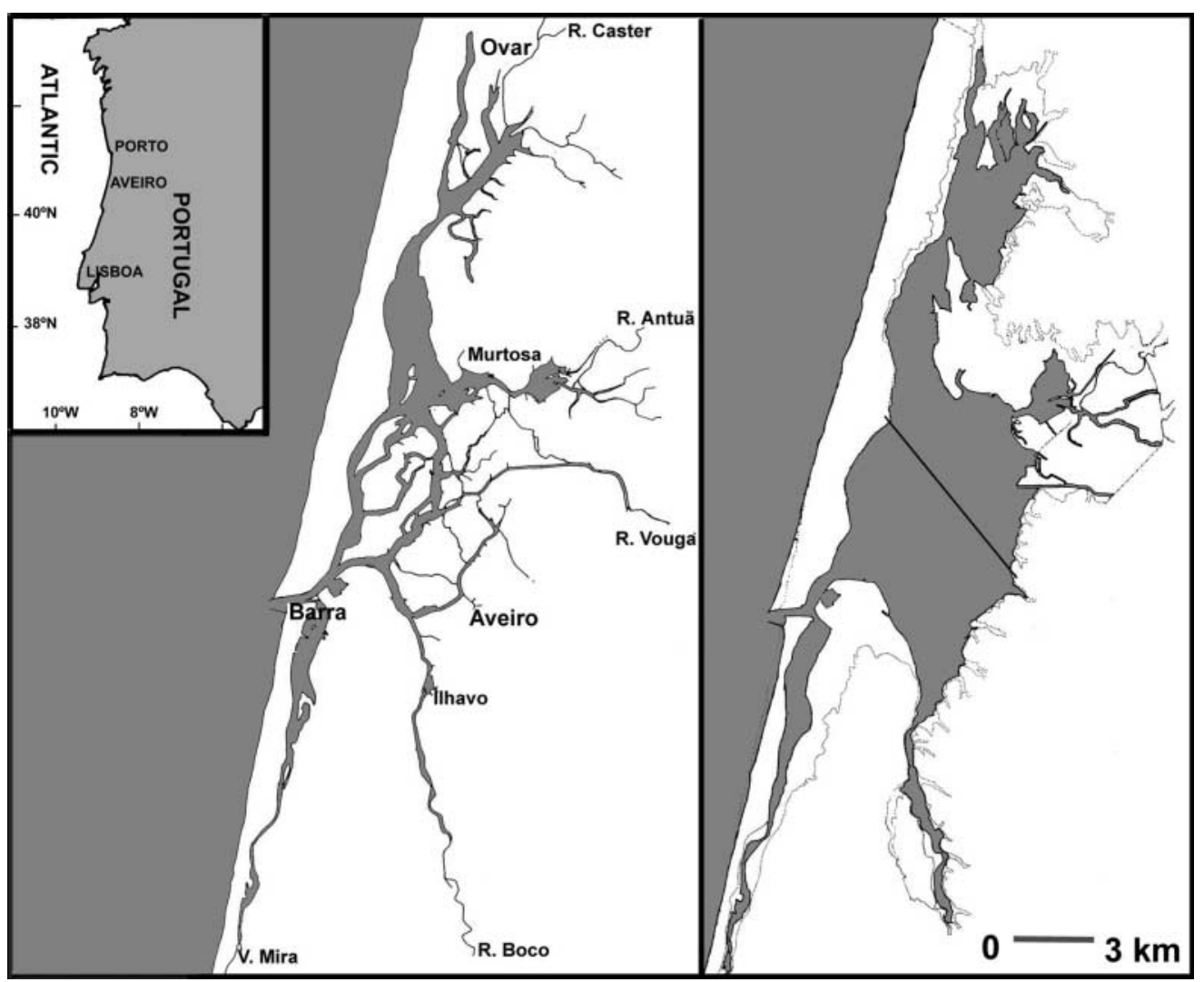

Fig. 1. The location (inset) and morphology of the Ria de Aveiro (left panel). The area covered by water at mean sea level is shaded. In the right panel, the area that is covered by water on the highest tides is shaded. The dotted line corresponds to the limit of alluvial deposits from river or lagoon origin. The black line corresponds to the profile of Fig. 4

low permeabilities and steep, mountainous slopes. The nature of the underlying geology, together with the climatic conditions of this region, characterised by an irregular temporal pattern of rainfall distribution, are the causes of large variations in river flows throughout the year. The discharges of most of the influents during late summer typically fall to ca $3 \mathrm{~m}^{3}$ $\mathrm{s}^{-1}$, whilst flows in winter and spring generally vary between 20 and $60 \mathrm{~m}^{3} \mathrm{~s}^{-1}$. However, the peak discharge of the River Vouga can be $>1000 \mathrm{~m}^{3} \mathrm{~s}^{-1}$ (DGRAH 1977), and in such events the influent rivers will collectively flood land bordering the inner areas of the lagoon.

Ocean tides propagate into the Ria de Aveiro through the single inlet, located to the north side of Barra town (Fig. 1). The tides observed near the mouth of the channel are semidiurnal, with a small daily inequality, having a mean amplitude of $1.9 \mathrm{~m}$, and a maximum amplitude of $3 \mathrm{~m}$ on the largest spring tides (Costa 1990). Inland from the Barra channel there is a progressive reduction in the amplitude of tides and a delay in the times of high and low water relative to those in the channel. The propagation of the tidal wave along the relatively narrow channel at Barra induces strong tidal currents in the upstream channel network. Since the mean annual fresh water inflow is small, the currents in these channels are almost totally dependent on tidal energy. Climate forcing causes a small variation in observed mean sea levels, which are $0.12 \mathrm{~m}$ higher from October to February relative to the period from March to September.

The annual average sediment load transported by the rivers into the lagoon was calculated by Teixeira (1994) to be $0.24 \times 10^{6} \mathrm{~m}^{3}$. The coarser fraction of sand was estimated to be $20 \%$ of the total load. Thus, most of the sediment transported by the rivers is silt and clay, which corresponds to the grain sizes of the sediments of the intertidal flats and salt marshes. The fluvial contribution to the sand that is present at the seaward side of the lagoon is thought to be very small.

Tidal currents are also strong in the ocean close to the inlet/outlet. However, in the near shore zone outside the lagoon, the most important forcing of water circulation is wind stress and wave action. The mean circulation corresponds to a north-south longshore current. The sediment volume transported annually in the 
littoral drift was estimated by Oliveira et al. (1982) to be $2 \times 10^{6} \mathrm{~m}^{3}$. The reduction of the supply of sediment from the Douro River to the north, due to the construction of dams, and the retention by jetties built for protecting some areas of the coastline, have caused a decline in the amount of sediment transported by littoral drift over the last 2 decades.

\section{MORPHOLOGICAL EVOLUTION OF RIA DE AVEIRO}

The origin and evolution of the Ria de Aveiro are related to the southward growth of the major sand spit which encloses the lagoon from the Atlantic Ocean side (west). Sand is transported along shore, principally in a north to south direction, by littoral drift, and sand accumulated on the beach is also moved southward by winds, forming sand dunes. A large area of sand dunes extends for some $100 \mathrm{~km}$ to the south of the Douro River. In the past, wind caused movement of these sand dunes, but they are now 'fixed' by pine woods.

The contemporary changes occurring in the Ria de Aveiro will be reviewed by taking into consideration its morphological evolution over the last $200 \mathrm{yr}$, as doc- umented by maps. Around $1800 \mathrm{AD}$, the ria was almost isolated from the Atlantic Ocean, due to the southward migration of the head of the major sand spit which today encloses the lagoon. Extension and growth of this spit was exerting a control on the natural evolution of the system, because the tidal amplitude became sharply reduced in the long and narrow natural channel connecting the lagoon to the ocean. In 1802, tidal ranges were between 0.07 and $0.13 \mathrm{~m}$ over most of the lagoon (Carvalho 1947). During wet periods, up to 9 mo in a yr, all of the area of the lagoon remained continually flooded by river water. Also, the beds of the influent rivers were being infilled by sediment derived from their catchment areas. The ria, at that time, was thus a choked coastal lagoon.

The trend of this natural evolution was halted in 1808 by the construction of a new inlet/outlet channel to the lagoon, fixed by a breakwater as shown in Fig. 2. This new inlet/outlet had a cross-sectional area of ca $1000 \mathrm{~m}^{2}$ and was located closer to the lagoon, $18 \mathrm{~km}$ to the north of the natural channel. In consequence, the tides within the lagoon increased in amplitude to $>1 \mathrm{~m}$. Furthermore, the River Vouga, which was naturally discharging to the north of the lagoon, was diverted to the west into a channel that connected more directly to the outlet (Fig. 2). This diversion brought changes that

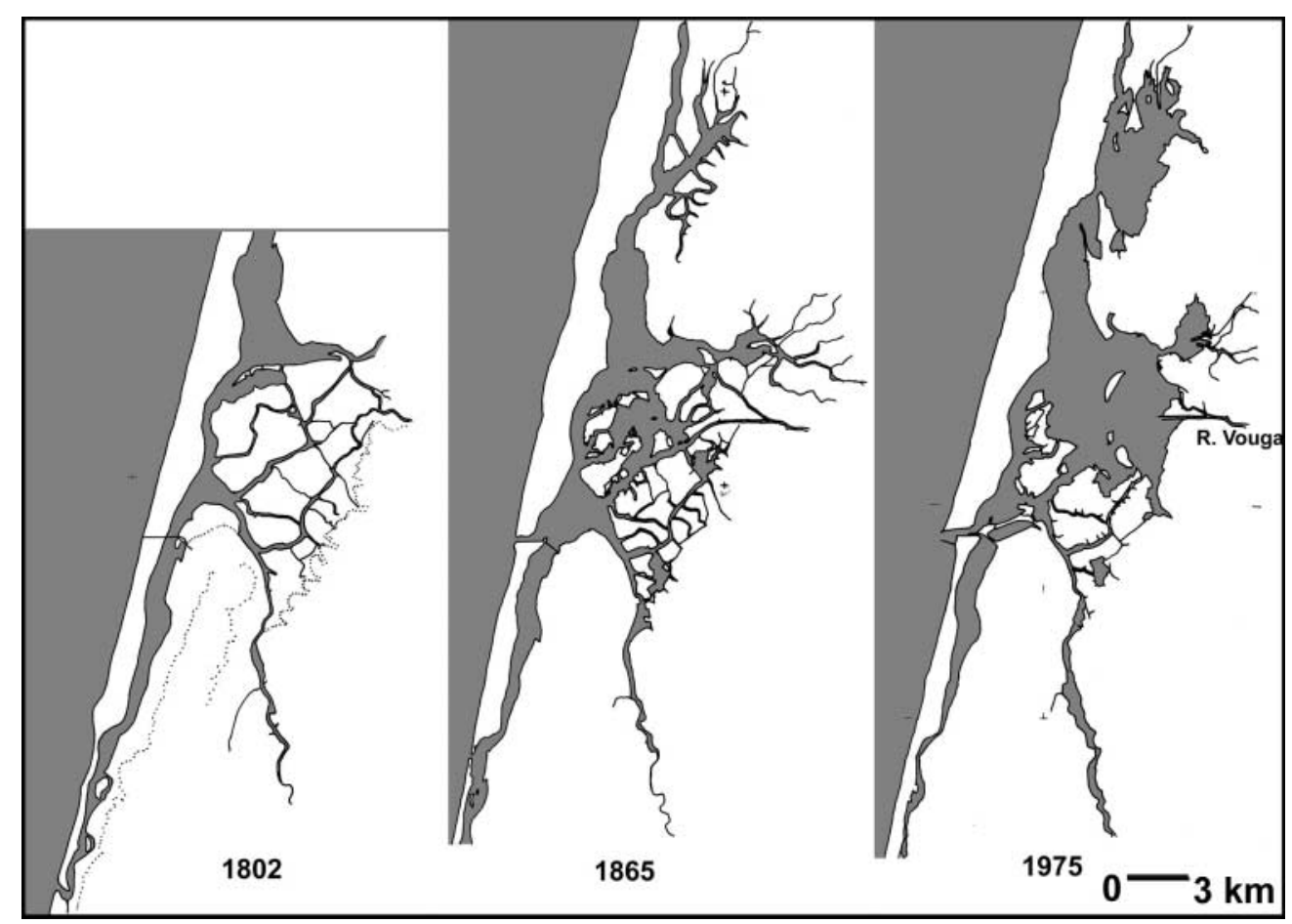

Fig. 2. Maps showing the area of the Ria de Aveiro covered by water at high water on a spring tide. The panel for 1802 represents the summer condition before the opening of the new inlet/outlet. The panel for 1865 shows that part of the central area of the ria initially flooded at high water. The panel for 1975 shows the increase of the area flooded at high water, due to tides of larger amplitude 
were beneficial to the economy of the region; to the expanding port of Aveiro; to salt production in the lagoon; and to agriculture, which became less subject to the adverse effects of river floods. Works to maintain the channel wide and deep enough for navigation to the port of Aveiro continue to this day. Such activities have become the major factor controlling the evolution of the lagoon to its present state.

Prior to 1936, the inlet/outlet channel was bordered on its northern side by a mobile sand embankment, which prevented the channel from deepening. Observations made by Missão Hidrográfica da Costa de Portugal (1934) indicate that the spring tidal amplitude varied from $>2 \mathrm{~m}$ close to the ocean to ca $1.1 \mathrm{~m}$ at a distance of $3 \mathrm{~km}$ upstream. The spring tidal range decreased further towards the interior of the lagoon, but a small tidal rise and fall could be observed as far landward as the channels of the influent rivers. This hydrographic regime allowed the rapid discharge of high river flows, thereby preventing flooding and the upstream accumulation of sediment loads. The currents created by tidal propagation into the lagoon were active in dispersing the sediments transported to the central area of the lagoon where the channels of the major rivers meet.

Several authors (Loureiro 1904, Leitão 1906, Nobre et al. 1915) have made assessments of the area of the lagoon that was permanently covered by water, varying from 60 to $80 \mathrm{~km}^{2}$. This area included some 270 salt pans, built over intertidal flats, which were enclosed by mud dikes, and covered an area of ca $17 \mathrm{~km}^{2}$ around the town of Aveiro. This area was also covered by water, but isolated from the tidal effect. Some marsh areas close to the Rivers Vouga and Antuã were also protected by dikes and used for agriculture i.e. rice fields and pastureland.

From 1936, the inlet/outlet channel was improved by means of a jetty to provide a better orientation to influent tidal flows (i.e. closer to parallel), and by a breakwater built on the north embankment. Later a second breakwater was built to the south of the channel. From 1986, the works included dredging the channel from the ocean as far upstream as the port of Aveiro, and extending the breakwater on the northern side further into the ocean. The most recent works, which still continue, involve dredging and the construction of walls to define the interior channels.

The cross-sectional area of the channel at Barra is now close to $4000 \mathrm{~m}^{2}$, and the upstream channels towards the port of Aveiro have similar cross-sections. The increase in cross-sectional area has caused a steady increase in the amplitude of tides inside the lagoon, contributing to the deepening of the main channels. A comparison of the morphology of the entrance to/exit from the ria system between 1865 and 1988 is shown in Fig. 3. Most of the old salt pans are now open to the tidal oscillation. The mud dikes that had not been reinforced have now been partially destroyed due to the increasing stresses imposed by the larger tidal amplitudes.

Two detailed bathymetric surveys have been carried out in the Ria de Aveiro, the first in 1952 and the second in 1987. By comparing results from these surveys, Rodrigues et al. (1989) concluded that an area of $45 \mathrm{~km}^{2}$, located below mean sea level was, on average, eroded by $1.3 \mathrm{~m}$ vertically. Some other, generally shallow, areas show accretion, but on a much smaller scale. The water depth profiles of Fig. 4 show that channels

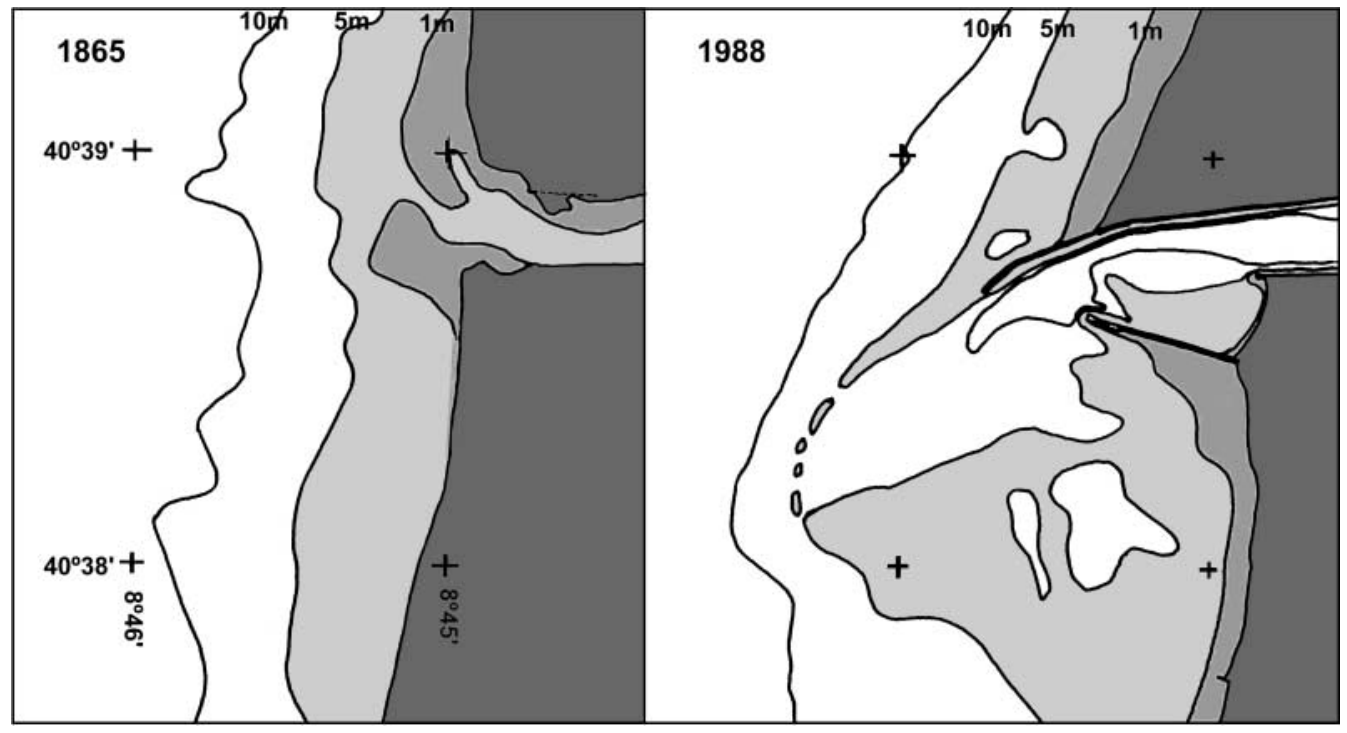

Fig. 3. Changes in bottom topography of the inlet/outlet channel (Barra) from 1865 to 1988 


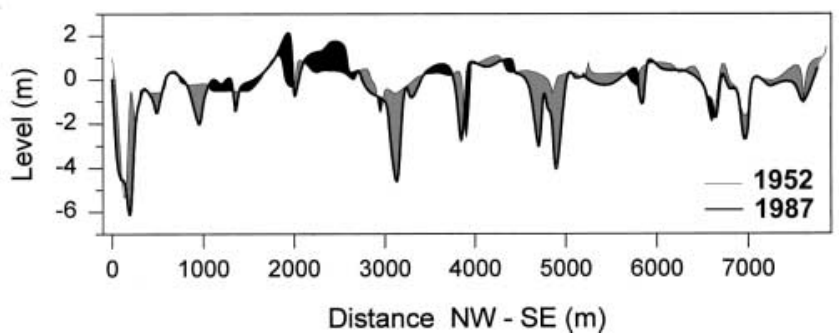

Fig. 4. Comparison of 2 bottom profiles, from Muranzel (NW) to Aveiro (SE), based on detailed bathymetric surveys carried out in 1952 and 1987. Areas marked in grey show erosion and areas marked in black show accretion

in the lagoon are widening and increasing in depth, while some of the mud flat areas are increasing in elevation as a result of sedimentation.

This trend suggests a larger capacity for sediment transport and dispersal, related to the increase in tidal currents. Some of this sediment will be exported to the ocean, but it is also known that sediment is imported from the ocean. However, the balance between the two cannot be ascertained. Only ca $1 / 3$ of the total volume of sediment removed from channels is accounted for by the volume of material dredged mainly from the Barra channel (Teixeira 1994). Most of the sediment eroded is therefore exported to the ocean. Some of this sediment can be found forming the ebb delta outside the inlet, which has grown considerably over time (Fig. 3).

\section{HYDROGRAPHIC CHANGES CAUSED BY THE BARRA CHANNEL}

The changes that will be described are related to the increase of tidal amplitude in the lagoon, caused by works carried out in the inlet/outlet channel. The hydrographic response to climate change, up until the present, is suggested to have been a minor cause for the rapid evolution observed. On consideration of the bottom topography of the lagoon of the Ria de Aveiro system, its shallow water column and the major influence of tides compared with the generally low fresh water inflows, it is anticipated that hydrographic conditions are mainly controlled by tidal flows.

It was reported by Carvalho (1947) that before the opening of the new channel in 1808, the water level of the lagoon was determined mainly by river flow. The winter level, during river floods, was up to $2 \mathrm{~m}$ higher than the summer level. In summer, the tidal oscillation was ca $0.1 \mathrm{~m}$, observed over an area of ca $50 \mathrm{~km}^{2}$, and this would have corresponded to a tidal prism of ca $5 \times 10^{6} \mathrm{~m}^{3}$. The flow speed in the channel close to the point of the new inlet, was then about $0.2 \mathrm{~m} \mathrm{~s}^{-1}$.
From 1808 to 1936, the inlet/outlet channel was shallow, as shown in the left panel of Fig. 3, so the tidal flows involved a large loss of energy. Thus, the bottom stress caused the tides in the lagoon to have the characteristics of a progressive wave, propagating at different speeds at high and low water. The tides in the lagoon could then possess a time lag of more than $6 \mathrm{~h}$ in the inner parts of channels, with the tidal amplitude of spring tides being ca $1 \mathrm{~m}$ over the central area of the lagoon. The subsequent deepening of channels has reduced the effect of energy loss such that the time lag is reduced and the tidal amplitude is increased. Thus, the increase in tidal amplitude is associated with a mean water level in the ria system closer to that of mean sea level (MSL). Detailed tidal data are not available for the inner channels during this period. Therefore, to estimate the tidal prism it is necessary to start from the known present conditions and make adjustments of mean water level, tidal amplitude and tidal phase.

Between 1936 and 1956, the breakwaters shown in the right panel of Fig. 3 were built, and the strong currents occurring in the inlet/outlet channel caused an increase in water depth, at some points to $>10 \mathrm{~m}$. The larger cross-section of the channel caused a smaller energy loss and the amplitude of tides inside the lagoon has increased steadily. The phase differences have reduced and mean levels approach MSL. During this period some studies of tides in Ria de Aveiro were undertaken (Abecasis 1951). These show that the tidal prism of the largest spring tides was up to $65 \times 10^{6} \mathrm{~m}^{3}$, for the channel conditions existing in 1951. This would correspond to flow speeds of $>2 \mathrm{~m} \mathrm{~s}^{-1}$. Table 1 summarises the change of the spring tidal amplitude at Barra, close to the inlet/outlet, and at S. Jacinto, $3 \mathrm{~km}$ inland.

The difference in the values between Barra and S. Jacinto shows that until 1936, the tidal amplitude was sharply reduced in the inlet channel. By 1963, an important change had occurred causing increases in tidal amplitude at all points of the ria. Near the inlet the increase continued until 1966, and in the interior of the ria continues to the present day. Thus, this $50 \mathrm{yr}$ interval (Table 1) may be divided into 2 phases: in the first ca 20 yr there were large increases in tidal amplitude at both stations, followed by more moderate increases during the last ca $30 \mathrm{yr}$.

Table 1. Amplitude (m) of spring tides according to navigation charts

\begin{tabular}{|lcccc|}
\hline & 1936 & 1963 & 1966 & 1987 \\
\hline Barra & 2.2 & 2.5 & 2.8 & 2.8 \\
S. Jacinto & 1.1 & 2.3 & 2.4 & 2.5 \\
\hline
\end{tabular}




\section{ANALYSIS OF RECENT HYDROGRAPHIC DATA}

Detailed surveys of bathymetry and tidal elevations, covering all areas of the Ria de Aveiro, were carried out in 1987/88. Tides were observed at some 30 locations distributed over the major channels of the lagoon system. The results were summarised by Costa (1990) and enable a detailed characterisation of tidal propagation within the Ria de Aveiro. In Table 2 are listed the amplitude $(A)$ and the phase $(g)$ of the tidal constituents larger than $0.03 \mathrm{~m}$, obtained from observations at Barra and Murtosa (Silva 1988).

A rise in mean water level, and a compound tide with the same low frequency of $\mathrm{Ms}_{\mathrm{f}}$ (Le Provost 1991) are generated inside the lagoon by shallow water effects. Also, the fourth diurnals $\mathrm{M}_{4}$ and $\mathrm{MS}_{4}$ gain more importance in the lagoon, as their amplitude ratio increases to ca $9 \%$. The asymmetry caused by these constituents also changes as the phase difference reduces from $253^{\circ}$ to $111^{\circ}$. However, the most important aspects are the reduction of amplitude and the long time lag associated with frictional mechanisms (Parker 1991).

A cubature method has been applied by Silva (1994) to calculate the volume of the tidal prism and the tidal flows. The method uses a square grid to represent the bed of the channels with grid levels being calculated from the 1987 bathymetric survey. The size of the grid elements was chosen according to the width of the channels. The size used was $50 \mathrm{~m}$, except for the north channel extending to Ovar, where the size was $100 \mathrm{~m}$. The area above mean water level, corresponding to salt mash and salt pans, was also included from an

Table 2. Amplitude $(A)$ and phase $(g)$ of tidal harmonic constituents at 2 locations in the Ria de Aveiro. Mean water level $\left(Z_{0}\right)$ relative to mean sea level, amplitude ratio and phase difference between $M_{4}$ and $M_{2}$ are also given. Harmonic constituents: $\mathrm{M}_{2}, \mathrm{~S}_{2}, \mathrm{~N}_{2}, \mathrm{~K}_{2}, \mathrm{v}_{2}$ (semi-diurnal), $\mathrm{K}_{1}, \mathrm{O}_{1}$ (diurnal), are astronomical tides; $\mathrm{M}_{4}, \mathrm{MS}_{4}$ (quarter-diurnal) and $\mathrm{Ms}_{\mathrm{f}}\left(\mathrm{MS}_{0}\right)$ are overtides and compound tides

\begin{tabular}{|lrrrr|}
\hline & \multicolumn{2}{c}{ Barra } & \multicolumn{2}{c|}{ Murtosa } \\
Constituent & $A(\mathrm{~m})$ & $g\left({ }^{\circ}\right)$ & $A(\mathrm{~m})$ & $g\left({ }^{\circ}\right)$ \\
\hline $\mathrm{M}_{2}$ & 0.962 & 108.6 & 0.588 & 166.0 \\
$\mathrm{~S}_{2}$ & 0.332 & 137.6 & 0.147 & 208.5 \\
$\mathrm{~N}_{2}$ & 0.201 & 90.6 & 0.099 & 156.4 \\
$\mathrm{~K}_{2}$ & 0.094 & 134.1 & 0.042 & 205.0 \\
$\mathrm{~K}_{1}$ & 0.061 & 79.0 & 0.043 & 133.3 \\
$\mathrm{O}_{1}$ & 0.055 & 334.4 & 0.042 & 32.5 \\
$\mathrm{v}_{2}$ & 0.042 & 99.1 & 0.034 & 136.1 \\
$\mathrm{M}_{4}$ & 0.039 & 324.2 & 0.053 & 220.8 \\
$\mathrm{MS}_{4}$ & 0.026 & 9.0 & 0.036 & 260.4 \\
$\mathrm{Ms}_{\mathrm{f}}\left(\mathrm{MS}_{0}\right)$ & & & 0.123 & 28.9 \\
$Z_{0}$ & 0.140 & & 0.376 & \\
$\mathrm{M}_{4} / \mathrm{M}_{2}$ & 0.041 & & 0.090 & \\
$2 \mathrm{M}_{2}-\mathrm{M}_{4}$ & & 253.0 & & 111.2 \\
\hline
\end{tabular}

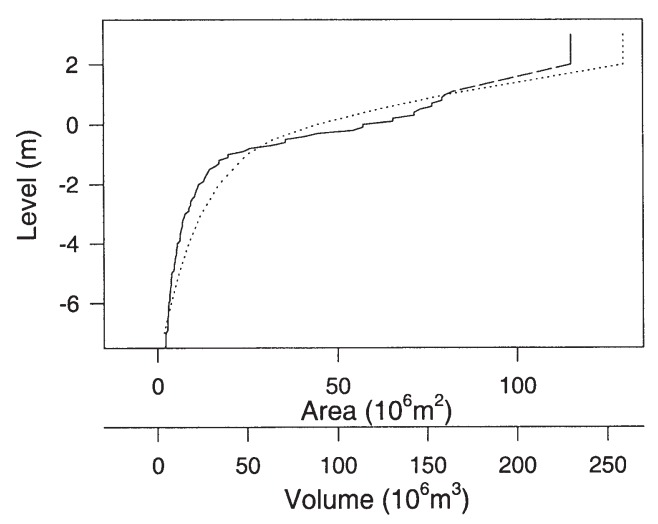

Fig. 5. Volume of water and area of the Ria de Aveiro. The solid line represents the area of the ria limited by a horizontal surface (million $\mathrm{m}^{2}$ ) as a function of elevation relative to mean sea level. The volume contained below that surface (million $\mathrm{m}^{3}$ ) is represented by the dotted line. The analysis was extended to $2 \mathrm{~m}$ above mean sea level

aero-photogrammetric survey carried out at the same time.

In the ria, the volumes of water contained in the channels increase sharply with the elevation of water surface, owing to the vast intertidal areas. Fig. 5 shows the area covered and the volume contained as a function of elevation relative to mean sea level. For the calculation of the volume of water present in the ria system at a given time, the phase differences and local mean water levels must be taken into consideration.

Tidal elevation at 19 stations along the 5 major channels of the ria were computed using the harmonic parameters of tidal constituents obtained for these locations. For the present study the spring tides occurring on 25 April 1990 were used. By this method, synoptic time series of tidal elevations, for points along the main channels of the ria, were obtained.

The use of the cubature method also depends on establishing an accurate mean water level for each location. This procedure is only possible when the series of observed water levels include the fortnightly and annual variations of daily mean level. At 6 of the locations these variations were identified (Silva 1994) and have been shown to vary with the distance $(D, \mathrm{~m})$ from the inlet/outlet. The linear relationship established for the local annual mean level, referred to Portuguese national mean sea level $(L, \mathrm{~m})$ is:

$$
L=0.17+1.8 \times 10^{-5} D
$$

Mean water levels derived from this relationship were added to predicted elevations, obtained by harmonic analysis, to calculate actual water levels. The volumes of water contained in the channels were calculated from these water levels at specific points along 


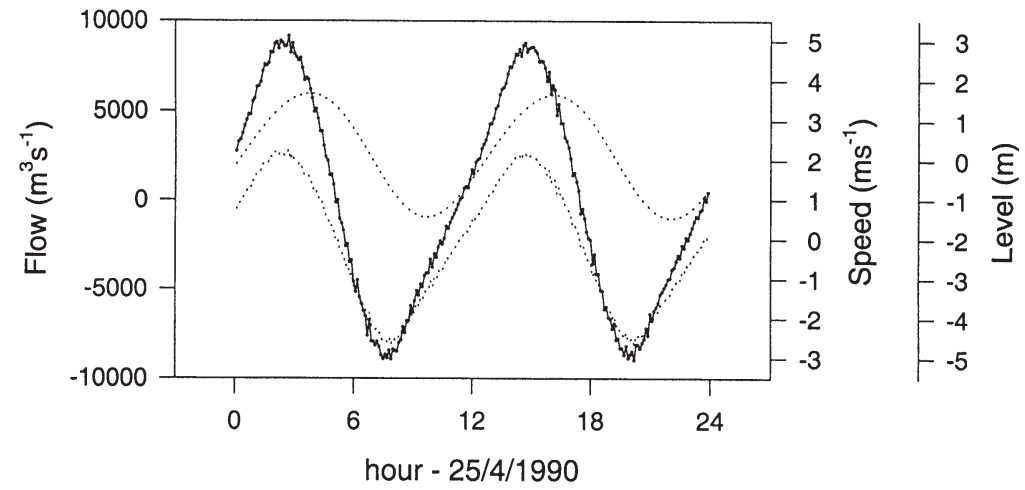
represents the total flow in the Barra channel caused by spring tides on 25 April 1990. The upper dotted line represents water level and the lower dotted line represents mean flow speed in the cross-section of the channel
Fig. 6. Characteristics of tides in the inlet of the Ria de Aveiro. The solid line

anthropogenic processes should be taken into consideration, regarding the future evolution of the ria. However the issues that will be addressed here are limited to the changes that can be caused directly by the evolving hydrographic conditions.

Based on the tide survey of 1988, the water levels in the central zone of the ria, which correspond to maximum and minimum volumes, are respectively, ca $1.4 \mathrm{~m}$ above MSL, and ca $1 \mathrm{~m}$ below MSL (Fig. 7). The total capacity of the ria system at the maximum level is ca $195 \times$ $10^{6} \mathrm{~m}^{3}$ (Fig. 5). This level is not reached over all the area, thus the volume at high water on a spring tide (25 April 1990) was calculated to be ca $180 \times 10^{6} \mathrm{~m}^{3}$.

The difference between these values the channels, using linear interpolation between the points. Tidal flows were then computed from the variations of water volume inside the channels,. The total flow, water level and speed in the Barra channel are displayed graphically in Fig. 6.

At Barra, the asymmetry in tidal elevation is small. However, the flood current stops $1.2 \mathrm{~h}$ after high water, and the ebb current stops $1.6 \mathrm{~h}$ after low water, causing the ebb to be $0.4 \mathrm{~h}$ longer than the flood. The phase difference between elevation and velocity is ca $50^{\circ}$. This value reflects the progressive wave nature of tides inside the ria. The propagation speed of high water and low water along 3 channels is shown in Fig. 7 , which also displays the water surface profiles at the moments when flood and ebb currents stop in the Barra channel. These times correspond, respectively, to the maximum and minimum volume of water inside the ria system. The tidal prism so defined is ca $111 \times$ $10^{6} \mathrm{~m}^{3}$, a value that is 1.7 times larger than the value calculated for 1951 conditions.

\section{TRENDS FOR FUTURE EVOLUTION}

The steady increase of tidal amplitude in the ria is the primary cause for a complex system response, involving interactions between physical, chemical and biological processes, which may have a destabilising effect on the dynamic equilibrium of the system. It is possible to identify the following processes as examples of this response: salinity increase; reduction of area covered by sea plants (Zostera and Ruppia); erosion of mud flats, salt marsh and salt pans; and redistribution of sediments between compartments of the system and the ocean.

For centuries, human action has been a major factor controlling the evolution of the ria system. Therefore, will be reduced by an increase in the tidal propagation speed inside the ria. The increase in the cross-section of most of the ria channels, extending inland from the

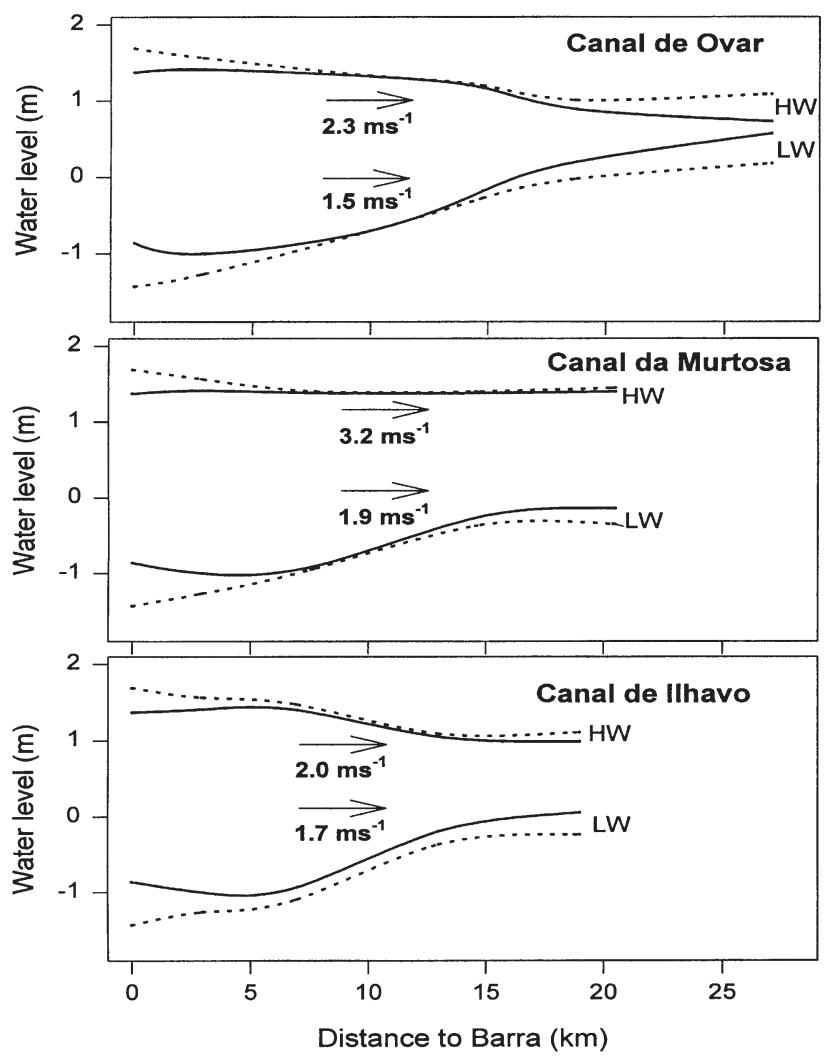

Fig. 7. Tidal propagation in the Ria de Aveiro. The solid lines define the water surface profiles at the moments when flood and ebb currents stop in the Barra channel. The dotted lines define the high water (HW) and low water (LW) along the 3 channels in the Ria de Aveiro. Arrows refer to the propagation speeds of high water and low water 
inlet/outlet, has already caused an increase in the velocity of tidal wave propagation. This trend has continued since 1988, causing higher high water levels at the landward ends of channels, while those reaches of channels close to the ocean are experiencing stronger currents.

Some areas now have a greater risk of flooding during high tide. These areas are located on the margins of the lagoon, and include the town of Aveiro and agricultural fields. In the case of Aveiro, it is observed that the levels of high water have increased, and the sea gates built in 1984 are now frequently submerged at high water on spring tides. Fields between the Rivers Vouga and Antuã are now more affected by tidal action causing an increase in salinity and harm to the soil. These fields are in the process of being protected by a new dike, built to prevent flooding during spring tides. Up to some $10 \mathrm{~km}$ inland from the inlet, the strong currents are causing erosion of the channel banks, especially in the area of old salt pans. This process is causing an increase in water turbidity and the potential release of pollutants from the resuspended sediment.

Another factor that can be discussed in this context is the trend for future rise of mean sea level. In the past, a slow increase in mean sea level would have been compensated by the rise of the bed, due to sedimentation and construction of salt pans. More recently, erosion of the channel beds has been observed, so any rise in sea level will cause an increase of both area and volume of the water mass. The increase in high water level will be similar to the increase in mean water level. For example, an increase from $1.4 \mathrm{~m}$ to $1.5 \mathrm{~m}$ above MSL will correspond to a $5 \%$ increase $(10 \times$ $10^{6} \mathrm{~m}^{3}$ ) in the capacity of the system. In addition, the increase in MSL will reinforce tidal propagation, which could lead to important changes in the dynamics of the ria system. The resulting increase of the tidal prism will potentially be $(195-180) \times 10^{6} \mathrm{~m}^{3}+10 \times 10^{6} \mathrm{~m}^{3}=25 \times$ $10^{6} \mathrm{~m}^{3}$, i.e. $22 \%$ of the present maximum value $(111 \times$ $10^{6} \mathrm{~m}^{3}$ ). The flooding of intertidal areas can potentially be controlled by the construction of dikes. However, this activity could also cause an increase in high water level, as in the case described by Kang (1999). The sand spit that shields the lagoon from the ocean would, however, be more difficult to protect in the context of a rapid sea level rise.
Acknowledgements. The use of unpublished bathymetric material was permitted by Junta Autonoma do Porto de Aveiro. Some tidal elevations time series and processing routines were obtained from Eng ${ }^{\circ}$ Mário Teles and Doutor Daniel Rodrigues.

\section{LITERATURE CITED}

Abecasis C (1951) O regime das embucaduras e o problema do melhoramento da barra de Aveiro. Dir Geral Serv Hidraulico, Lisboa

Carvalho LG (1947) Memória descritiva. Arquivo do Distrito de Aveiro XIII:20-113

Costa CNL (1990) Propagação da maré na Ria de Aveiro. Projecto MC.06.01.90, Divisão de Marés e Correntes, Instituto Hidrográfico, Lisboa

DGRAH (1977) Anuário dos Serviços Hidráulicos: Hidrometria. 1976-1977 Direcção Geral dos Recursos e Aproveitamentos Hidráulicos, Lisboa

Kang JW (1999) Changes in tidal characteristics as a result of the construction of sea-dike/sea-walls in the Mokpo coastal zone in Korea. Estuar Coast Shelf Sci 48:429-438

Leitão (1906) A bacia hydrographica de Aveiro e a salubridade publica. Imprensa Portugueza, Porto

Le Provost C (1991) Generation of overtides and compound tides (Review). In: Parker BB (ed) Tidal hydrodynamics. John Wiley \& Son, New York, p 269-295

Loureiro A (1904) Porto de Aveiro. Imprensa Nacional, Lisboa

Missão Hidrográfica da Costa de Portugal (1934) Plano hidrográfico da Barra e Foz da Ria de Aveiro. Administração do Porto de Aveiro, Forte da Barra

Nobre A, Afreixo J, Macedo J (1915) A Ria de Aveiro. Imprensa Nacional, Lisboa

Oliveira IM, Valle FA, Miranda FC (1982) Litoral problems in the Portuguese West Coast. In: Edge BL (ed) Proc 18th Coast Eng Conf Vol III. American Society of Civil Engineers, New York, p 1950-1969

Parker BB (1991) The relative importance of the various nonlinear mechanisms in a wide range of tidal interactions (Review). In: Parker BB (ed) Tidal hydrodynamics. John Wiley \& Son, New York, p 237-268

Rodrigues A, Dias JMA (1989) Evolução pós-glaciária da plataforma continental Portuguesa a norte do Cabo Mondego. Em Anais do Instituto Hidrográfico, Lisboa, No. 10, p 39-50

Rodrigues D, Teles M, del Negro M, Ventura A, Rita A (1989) Modelação matemática da Ria de Aveiro. Relatório de Progressão, Hidroprojecto, Lisboa

Silva FC (1988) Marés no cais dos bicos, REL.FT.MC.05/87. Anexo I. Apendice 5. Instituto Hidrográfico, Lisboa

Silva JF (1994) Circulação da água na Ria de Aveiro-contribuição para o estudo da qualidade da água. Tese de Doutoramento, Universidade de Aveiro

Teixeira SL (1994) Dinâmica morfossedimentar da Ria de Aveiro (Portugal). Tese de Doutoramento, Universidade de Lisboa

Proofs received from author(s): July 9, 2001 